Institute and Herlev Hospital for providing histological material. We gratefully acknowledge the technical assistance of Mrs Anneliese Persson. The study was supported by grants from the Danish Cancer Society and the Danish Medical Research Council.

\section{References}

${ }^{1}$ Hamilton JB, Gilbert JB. Studies in malignant tumors of the testis. IV Bilateral testicular cancer. Incidence, nature, and bearing upon management of the patient with a single testicular cancer. Cancer Res 1942;2: 125-9.

2 Pugh RCB, ed. Pathology of the testis. Oxford: Blackwell Scientific Publications, 1976.

${ }^{3}$ Sokal M, Peckham MJ, Hendry WF. Bilateral germ cell tumours of the testis. Br $\mathcal{F}$ Urol 1980;52:158-62.

4 Skakkebæk NE. Possible carcinoma-in-situ of the testis. Lancet 1972;ii: 516-7.

${ }^{5}$ Skakkebæk NE. Carcinoma in situ of the testis : frequency and relationship to invasive germ cell tumours in infertile men. Histopathology 1978;2: 157-70.

- Berthelsen JG, Skakkebæk NE, Mogensen P, Sørensen BL. Incidence of carcinoma in situ of germ cells in contralateral testis of men with testicular tumours. Br Med F 1979;ii:363-4.
7 Schultz HP, Arends J, Barlebo H, et al. The Danish testicular carcinoma study (DATECA). Dan Med Bull (in press).

${ }^{8}$ Lillie RD, Fullmer HM. Histopathologic technic and practical histochemistry. 4th ed. New York: McGraw-Hill, 1976.

${ }^{9}$ Rowley MJ, Heller CG. The testicular biopsy: surgical procedure, fixation, and staining technics. Fertil Steril 1966;17:177-86.

10 Conover WJ. Practical nonparametric statistics. 2nd ed. New York: John Wiley \& Sons, 1980.

11 Mostofi FK, Sobin LH. Histological typing of testis tumours. In: International histological classification of tumours, No 16. Geneva: World Health Organisation, 1977.

1. Batata MA, Chu FCH, Hilaris BS, Whitmore WF, Golbey RB. Testicular cancer in cryptorchids. Cancer $1982 ; 49: 1023-30$.

13 Berthelsen JG, Skakkebæk NE. Gonadal function in men with testis cancer. Fertil Steril (in press).

14 Blandy JP, Hope-Stone HF, Dayan AD. Tumours of the testicle. London: William Heinemann, 1970.

15 Skakkebæk NE, Berthelsen JG, Visfeldt J. Clinical aspects of testicular carcinoma-in-situ. Int $\mathcal{F}$ Androl 1981 ;suppl 4 : 153-62.

16 Anonymous. Testicular biopsy for early detection of testicular tumour. Br Med F 1980;i:426-7.

17 Berthelsen JG, Skakkebæk NE. Distribution of carcinoma-in-situ in testes from infertile men. Int $\mathcal{F}$ Androl 1981 ;suppl 4:172-84.

(Accepted 9 September 1982)

\title{
Erythropoietin and renal function in sickle-cell disease
}

\author{
A G MORGAN，CAROLYN A GRUBER，G R SERJEANT
}

\begin{abstract}
The relations between haemoglobin concentration, creatinine clearance, and the serum concentration of erythropoiesis-stimulating factor were assessed in 31 patients with homozygous sickle-cell disease. Haemoglobin concentrations fell significantly with decreasing creatinine clearance $(\mathbf{r}=0.58, \quad p<0.001)$ and were positively correlated with the concentration of erythropoiesis-stimulating factor $(r=0.65, p<0.001)$.

These observations suggest that erythropoietin concentration is the factor limiting production of red cells in sickle-cell disease with renal insufficiency and have implications for treatment.
\end{abstract}

\section{Introduction}

A previous study in patients with homozygous sickle-cell disease aged over $40^{1}$ indicated a strong positive correlation between haemoglobin concentration and creatinine clearance. Haemoglobin concentrations appeared to be adversely affected by fairly minor degrees of renal insufficiency, and we postulated that the bone marrow might be very sensitive to reduced erythropoietin concentrations. We investigated this possibility further by measuring serum concentrations of erythropoiesisstimulating factor, renal function, and haemoglobin concentrations in 31 adults with sickle-cell disease who were in a steady state (that is, free of acute complications of their disease) at the time of study.

University of the West Indies, Kingston 7, Jamaica

A G MORGAN, MD, MRCP, Wellcome senior lecturer, department of medicine (present address: medical unit, London Hospital Medical College, London E1 2AD)

G R SERJEANT, MD, FRCP, director, Medical Research Council laboratories

Upjohn Company, Kalamazoo, Michigan 49001, USA

CAROLYN A GRUBER, BA, research biologist, medical development and clinical laboratory research

\section{Patients and methods}

Patients with sickle-cell disease were chosen from those attending the sickle-cell clinic of the University Hospital of the West Indies, Jamaica, on the basis of their willingness to take part in the study. Each was admitted electively to hospital when free of acute complications of their disease. The diagnosis of sickle-cell disease was based on a single major haemoglobin band in the position of haemoglobin $S$ on cellulose acetate and agar-gel electrophoresis, compatible haemoglobin $\mathrm{A}_{2}$ concentrations, and family study when possible. No patient had received a transfusion within three months, and only two had been included in the earlier study. ${ }^{1}$

Creatinine clearance was determined from two consecutive $\overrightarrow{\bar{a}}$ 24-hour collections of urine and accompanying measurements of 3 serum creatinine concentration, and the result was expressed as the mean of the two estimations, corrected for surface area derived from $\overline{0}$ height and weight. Blood was drawn for measurement of serum urea concentration and standard haematological variables. Erythropoiesisstimulating factor was measured by a modification of the fetal mouse liver cell assay described by Wardle et al ${ }^{2}$ using sera stored without $\frac{\sigma}{\partial}$ preservative at $-70^{\circ} \mathrm{C}$ and thawed only once, just before the 3 estimation. After overnight incubation of cell cultures in the presence $\delta$ of either test serum or pooled normal serum supplemented with 3 sheep erythropoietin (stage III, Connaught Laboratories) activity of erythroid precursor cells was measured by the rate of incorporation of iron-59-labelled ferrous citrate into haem. Differences in uptake $N$ of ${ }^{59} \mathrm{Fe}$ because of differences in the iron content of sera were pre- $D$ vented by adding an excess of human transferrin. The mean normal values for this laboratory in 11 male and 10 female American subjects were $12 \cdot 8 \mathrm{U} / 1$ (range 4.5-19.8 U/1) and 17.2 U/1 (range 10.8-27.0 U/1) 0 respectively.

Student's $t$ test and linear regression were used for statistical $\sigma$ testing of results. As noted by others, ${ }^{3}$ concentrations of erythropoiesis- 0 stimulating factor had a skewed distribution, and logarithmic transformation was therefore performed before analysis.

\section{Results}

The study group consisted of 11 men and 20 women with a mean age of $37 \cdot 1$ years (range $15-66$ years). Five were already known to have renal failure (creatinine clearance $4-23 \mathrm{ml} / \mathrm{min} / 1.73 \mathrm{~m}^{2}$ ) ac- 8 companied by appreciable anaemia (haemoglobin concentration $3 \cdot 0-4 \cdot 9 \mathrm{~g} / \mathrm{dl}$ ). Two of these (women aged 64 and 65 years) had been 
included in our earlier report: each had had slowly worsening anaemia and loss of renal function for which no explanation other than sickle-cell disease could be found. Of the other patients with known renal failure, one, a 50-year-old woman, had had an episode of the nephrotic syndrome nine years earlier followed by progressive loss of renal function, while a 48-year-old man and a 30-year-old woman had been found to be uraemic when investigated because of worsening anaemia. Histology in two patients (one at necropsy and one at biopsy) indicated changes typical of older patients with sicklecell disease and no evidence of an inflammatory glomerulonephritis. In addition to these patients a further 12 were found to have clinically unsuspected mild renal impairment (creatinine clearance less than $100 \mathrm{ml} / \mathrm{min} / 1.73 \mathrm{~m}^{2}$ ) and haemoglobin concentrations ranging from 5.4 to $11.0 \mathrm{~g} / \mathrm{dl}$.

Haemoglobin concentrations ranged from 3.0 to $11.0 \mathrm{~g} / \mathrm{dl}$ and showed a weak negative correlation with age $(\mathrm{r}=-0.48, \mathrm{p}<0.01)$. Creatinine clearance ranged from 4 to $191 \mathrm{ml} / \mathrm{min} / 1.73 \mathrm{~m}^{2}$ and fell significantly with age $(r=-0.66, p<0.001)$. The relation between haemoglobin concentration and creatinine clearance (fig 1) was similar to that found in patients over 40 years old, ${ }^{1}$ with a significant positive correlation $(r=0.58, p<0.001)$. As before, the effect of renal function on haemoglobin concentration appeared to be strongest in patients with a creatinine clearance of less than $100 \mathrm{ml} / \mathrm{min} / 1.73 \mathrm{~m}^{2}$.

Concentrations of erythropoiesis-stimulating factor ranged from $2 \cdot 1$ to $21.9 \mathrm{U} / 1$. There was a strong correlation between haemoglobin concentration and the concentration of the factor (fig $2 ; r=0.65$, $p<0.001$ ), and this was also strongest in patients with a creatinine clearance of less than $100 \mathrm{ml} / \mathrm{min} / 1.73 \mathrm{~m}^{2}$. The concentration of erythropoiesis-stimulating factor was correlated positively with creatinine clearance (fig 3; r $=0.61, \mathrm{p}<0.001$ ) and inversely with serum urea concentration $(\mathrm{r}=0.58, \mathrm{p}<0.001)$.

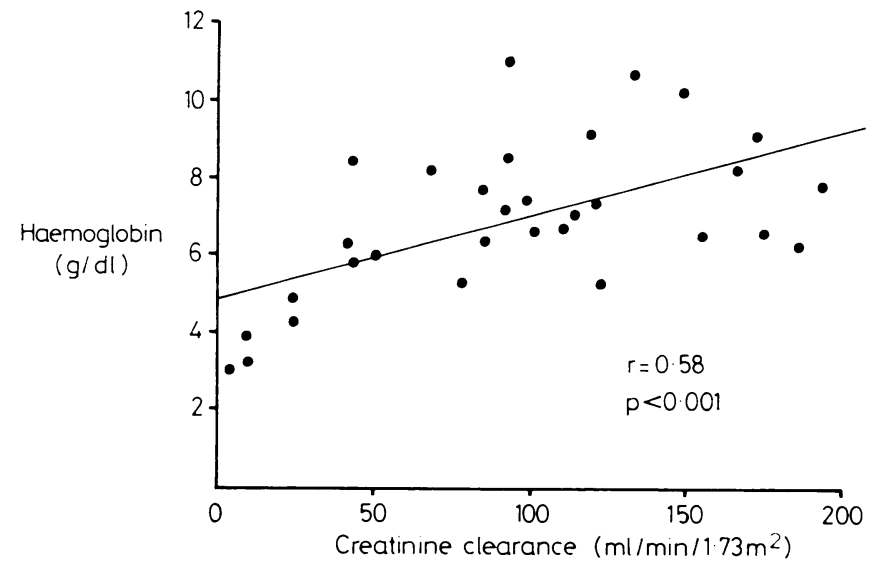

FIG 1-Relation between haemoglobin concentration and creatinine clearance.

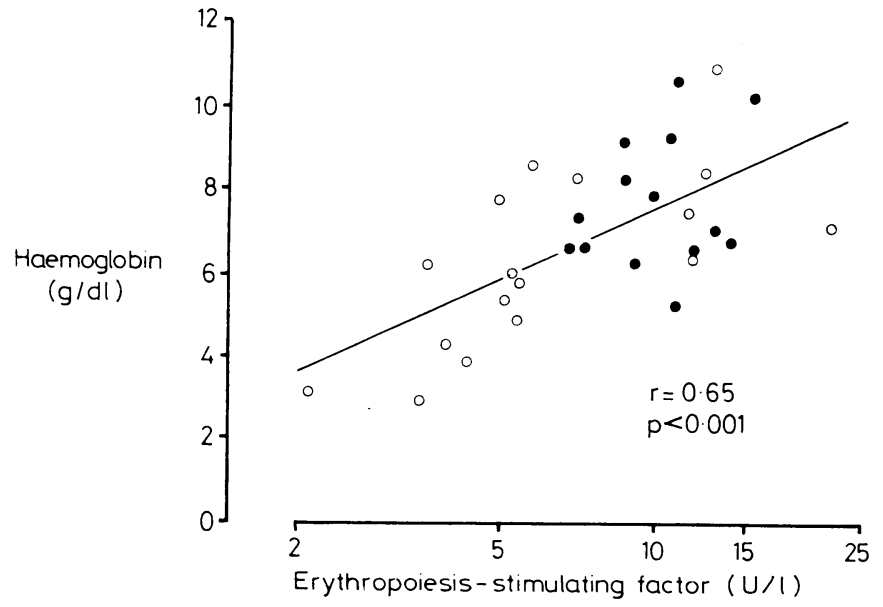

FIG 2-Relation between haemoglobin concentration and serum concentration of erythropoiesis-stimulating factor. Open circles indicate patients with creatinine clearance below $100 \mathrm{ml} / \mathrm{min} / 1.73 \mathrm{~m}^{2}$.

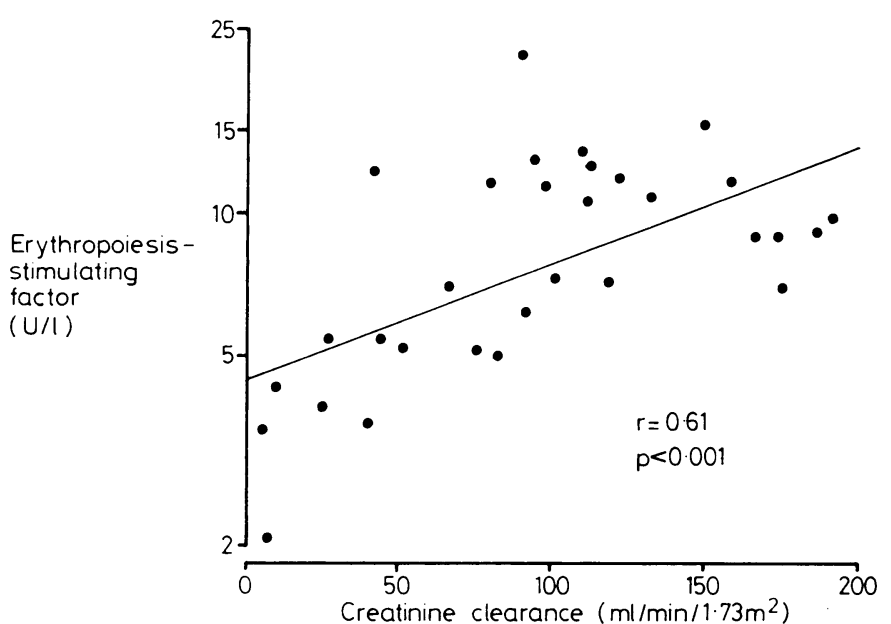

FIG 3-Relation between serum concentration of erythropoiesis-stimulating factor and creatinine clearance.

There was no relation between the percentage reticulocyte count and haemoglobin concentration $(r=-0 \cdot 19)$, and the patients with a fairly low creatinine clearance (less than $100 \mathrm{ml} / \mathrm{min} / 1.73 \mathrm{~m}^{2}$ ) had lower absolute reticulocyte counts (mean \pm SD: $212 \pm 91 \times 10^{\%} / 1$ ) than the remainder of the group $\left(323 \pm 159 \times 10^{9} / 1 ; \mathrm{p}<0.05\right)$, supporting the hypothesis that marrow hypoplasia was responsible for the lower haemoglobin concentrations.

\section{Discussion}

Published reports show that in sickle-cell disease erythropoietin concentrations rise in response to a fall in haemoglobin concentration as in aplastic crisis. ${ }^{4}{ }^{5}$ Though reports have not always made clinical details clear, it appears that serum erythropoietin concentrations in asymptomatic patients may be either normal or raised and are negatively correlated with haemoglobin concentration..$^{5-7}$ Any increase above normal, however, is less than that observed in other anaemic states with similar haemoglobin concentrations, ${ }^{36}$ perhaps because reduced oxygen affinity in sickle-cell disease makes tissue hypoxia (the stimulus to erythropoietin production) unusual in patients with steadystate haemoglobin concentrations. This may explain our observation that none of the 31 patients had a concentration of erythropoiesis-stimulating factor above the normal range. The expanded and hyperactive erythron in sickle-cell disease can therefore function with normal serum erythropoietin concentrations, although it is possible that the rate of production of erythropoietin is high and that the hormone is rapidly consumed by active marrow cells. ${ }^{8}$

Our present results agree with the earlier findings that low haemoglobin concentrations in patients with steady-state sickle-cell disease are associated with renal insufficiency and that this phenomenon is particularly characteristic of patients over 40 years old. ${ }^{1}$ Haemolysis consequent on uraemia is unlikely to contribute to the anaemia since reticulocyte counts were not raised, and the correlations between concentrations of haemoglobin and erythropoiesis-stimulating factor and between the concentration of the factor and creatinine clearance suggest that reduced production of erythropoietin is responsible. The correlation between concentrations of haemoglobin and erythropoiesis-stimulating factor was most evident in those patients with a fairly low creatinine clearance, which shows that the erythropoietin concentration becomes the important limiting factor in red-cell production only when renal insufficiency is present.

In most reports of bioassays of erythropoietin in chronic renal failure concentrations are either below normal or raised to a lower degree than might be expected for the extent of anaemia, ${ }^{9-12}$ whereas immunological methods have produced 
values well in excess of those expected, ${ }^{13} 14$ leading to the suggestion that either circulating erythropoietin is inactive or an inhibitor is present. The effects of differing types of renal disease and of haemodialysis are unknown, and our patients represented an unusual opportunity to examine the interrelations of haemoglobin concentration, erythropoietin concentration, and renal function without these complicating factors. All test sera stimulated the erythropoietic activity of the culture system, but the extent of stimulation might possibly have been limited by the presence of uraemic toxins. This is unlikely, however, because few patients were more than mildly uraemic. All except three had serum urea concentrations below $16.0 \mathrm{mmol} / 1(96 \mathrm{mg} / 100 \mathrm{ml})$ and serum creatinine concentrations below $220 \mu \mathrm{mol} / \mathrm{l}(2.5 \mathrm{mg} / 100 \mathrm{ml})$, values that are not usually associated with uraemic complications in people without sickle-cell disease. Thus glomerular function as measured by creatinine clearance appears to be closely related to capacity to produce erythropoietin.

Progressive renal failure is common in older patients with sickle-cell disease ${ }^{1}$ and is one of the commonest causes of death in those aged over $30 . .^{15}$ The mechanism is poorly understood but is reflected histologically in progressive glomerular damage and cortical scarring, and functionally in reduced production of erythropoietin and falling haemoglobin concentration. The common clinical presentation is of worsening anaemia together with heart failure that further compromises renal function. Survival may be prolonged by chronic transfusion, but since the fall in haemoglobin concentration appears to be determined predominantly by low erythropoietin concentrations it might be amenable to treatment with bone-marrow stimulants such as steroids or prostaglandins.

We gratefully acknowledge the technical help of $\mathrm{Mr} \mathrm{C} \mathrm{W} \mathrm{Benjamin}$ and the advice of Drs R L Lange and M N Brunden.

\section{References}

1 Morgan AG, Serjeant GR. Renal function in patients over 40 with $\stackrel{\varrho}{c}$ homozygous sickle-cell disease. $\mathrm{Br}$ Med $\mathcal{F} 1981$;282:1181-3.

2 Wardle DFH, Baker I, Malpas JS, Wrigley PFM. Bioassay of erythro- $\widehat{C}$ poietin using foetal mouse liver cells. Br $\mathcal{F}$ Haematol 1973;24:49-56.

${ }^{3}$ de Klerk G, Rosengarten PCJ, Vet JWM, Goudsmit R. Serum erythropoietin (ESF) titers in anemia. Blood 1981;58:1164-70.

4 Okcuoglu A. Erythropoietin in acute erythoblastopenia of sickle cell $\mathbb{\infty}$ anemia. Turk f Pediatr 1964;6:225-32.

${ }^{5}$ Hammond D, Shore N, Movassaghi N. Production, utilization and excretion of erythropoietin. I Chronic anemias. II Aplastic crisis. $\vec{F}$ III Erythropoietic effects of normal plasma. Ann NY Acad Sci 1968; $\stackrel{\mathcal{O}}{+}$ 149:516-27.

${ }^{6}$ Alexanian R. Erythropoietin excretion in bone marrow failure and $\frac{C}{5}$ hemolytic anemia. F Lab Clin Med 1973;82:438-45.

${ }^{7}$ Haddy TB, Lusher JM, Hendriks S, Trosko BK. Erythropoiesis in sickle cell anaemia during acute infection and crisis. Scand $\mathcal{f}$ Haematol $\mathbb{Q}$ $1979 ; 22: 289-95$

${ }^{8}$ Stohlman F, Brecher G. Hormonal regulation of erythropoiesis. V. Relationship of plasma erythropoietin level to bone marrow activity. $\overrightarrow{0}$ Proc Soc Exp Biol Med 1959;100:40-3.

${ }^{9}$ Naets J-P, Heuse AF. Measurement of erythropoiesis stimulating factor $\overrightarrow{\vec{c}}$ in anemic patients with and without renal disease. $\mathrm{f} \mathrm{Lab} \mathrm{Clin} \mathrm{Med} \mathrm{O}$ $1962 ; 60: 365-74$

${ }^{10}$ Zucker S, Lysik RM, Mohammad G. Erythropoiesis in chronic renal disease. F Lab Clin Med 1976;88:528-35.

11 Caro J, Brown S, Miller O, Murray T, Erslev AJ. Erythropoietin levels $\underset{0}{\infty}$ in uremic nephric and anephric patients. F Lab Clin Med 1979;33:449-57.

${ }^{12}$ Radtke H, Claussner A, Erbes PM, Scheuermann EH, Schoeppe W, W Koch KM. Serum erythropoietin concentration in chronic renal gु failure: relationship to degree of anemia and excretory renal function. Blood 1979;54:877-84.

${ }^{13}$ Lertora JJL, Dargon PA, Rege AB, Fisher JW. Studies on a radioimmunoassay for human erythropoietin. 7 Lab Clin Med 1975;86:140-51.

${ }^{14}$ Lange RD, Ichiki AT. Immunological studies of erythropoietin. In: Fisher JW, ed. Kidney hormones. Vol II. Erythropoietin. London: $三$ Academic Press, 1977: 111-49.

15 Thomas AN, Pattinson C, Serjeant GR. Causes of death in sickle-cell $\mathbb{D}$ disease in Jamaica. Br Med $\mathcal{F} 1982 ; 285: 633-5$.

(Accepted 4 October 1982)

\title{
Effects of prostaglandin $E_{1}$ on microvascular haemodynamics in progressive systemic sclerosis
}

\author{
M F R MARTIN, J E TOOKE
}

\begin{abstract}
The effects of prostaglandin $E_{1}$ infusion on nailfold capillary haemodynamics were studied in eight patients with Raynaud's phenomenon secondary to progressive systemic sclerosis. Using a modified Landis microinjection technique the mean (ISEM) transcapillary pressure gradient was increased during and six weeks after infusion by $13.9 \pm 3.2 \mathrm{~cm} \mathrm{H}_{2} \mathrm{O}(\mathrm{p}<0.05)$ and $5.5 \pm$ $2.5 \mathrm{~cm} \mathrm{H}_{2} \mathrm{O}(\mathbf{p}<0.05)$ respectively. Capillary red cell velocity measured in two patients by video television microscopy also increased during and after infusion with prostaglandin $\mathrm{E}_{1}$. Six patients claimed subjective benefit and in three their ulcers healed. These findings support
\end{abstract}

University Departments of Medicine and Rheumatology, Leeds General Infirmary, Leeds LS1 3EX

M F R MARTIN, MA, MRCP, senior registrar in rheumatology

J E TOOKE, MSC, MRCP, lecturer in medicine the observed beneficial effect of prostaglandin $E_{1}$ and $\delta$ suggest that it improves the nutritive capillary circula- $₹$ tion by lowering precapillary resistance.

\section{Introduction}

The vascular abnormalities found in progressive systemic $\tilde{N}$ sclerosis constitute a prominent feature of the disease and mainly affect the microvascular circulation. ${ }^{1}$ This association has led $\underset{\sigma}{ }$ some workers to conclude that a microangiopathy might repre- 0 sent the underlying cause of the disease. ${ }^{2}$ Raynaud's phenomenon $\mathbb{D}$ is a common and often early feature of the condition and the ? characteristic attacks of digital exsanguination may result in $\underset{T}{0}$ painful ischaemic ulceration, occasionally leading to gangrene that requires amputation.

Objective assessment of treatment efficacy for Raynaud's $\stackrel{\mathbb{D}}{2}$ phenomenon associated with progressive systemic sclerosis has proved difficult, partly owing to the specialised nature of the $\delta$ circulation in the hand. Conventional assessment using radio- $\frac{0}{0}$ metry, thermography, or plethysmography cannot distinguish 